\title{
Sexstillingen for deg!
}

Lenge trodde jeg at journalister var farlige. Denne frykten var innpodet helt fra legestudiets karikerte trussel om å «havne på forsiden av VG» dersom man skulle komme til å gjøre en feil i sin fremtidige legegjerning. Etter noen års omgang med journalister i ulike roller er frykten dempet betydelig. Jeg har opplevd mange mediearenaer der det er fullt mulig å formidle nyanser og kunne samtale med reflekterte journalister. Selvsagt finnes det redaksjoner på heksejakt, men i det store og hele er ikke problemet at journalistene er farlige. Det er heller at de er for lite farlige i sin omgang med helsestoff.

Norsk helsejournalistikk en tilfeldig valgt dag i slutten av august 2010: På Dagbladets forside lyser: «Åtte kreftvarsler du må se opp for - Dette må du sjekke! SE LISTA» (1). Avisen følger opp saken på sine helsenettsider, ledsaget av et nærbilde av brystvorten på et ungt og yppig kvinnebryst samt oppslag som «Mor helte avløpsrens over to år gammel datter» og «P-piller gjør deg smartere». NRKs helsenettssider toppes denne dagen av «Rask sex er best» og preges ellers av «Sexstillingen for deg» og «Loppetyfus i Sverige».

Kritisk og nyansert journalistikk fordrer innsikt. Ingen medier ville la økonomiredaksjonen fylle spalter, sendeflater eller nettsider med omtrentligheter og uimotsagt egenreklame fra tunge industriaktører eller la en matjournalist dekke en viktig fotballkamp. Helsejournalistikken, derimot, er ofte arenaen for tvilsomme «saker som selger» og for journalisten som mikrofonstativ, enten kildene er alternativterapeuter med mirakelkurer, helsemyndigheter eller titteltunge professorer med ønske om økte ressurser til eget forskningsmiljø.

At leger beklager seg over helsejournalistikken, er ikke nytt. Allerede i 1947 ble norske avisredaksjoner på lederplass i Tidsskriftet oppfordret til å skaffe seg faste medisinske medarbeidere og å drive «saklig opplysning» (2). Tiden for «saklig opplysning» som ideal i helsejournalistikken bør være forbi. Isteden trengs det kunnskapsrike helseredaksjoner som kan hente frem de viktige sakene, stille de kritiske spørsmålene og hjelpe lesere og seere til å orientere seg. Og mens vi i takt med endringene i samfunnets maktstrukturer har sett økt satsing på næringslivs- og økonomijournalistikk i mediene (3), er ikke helsestoffet blitt prioritert på samme måte.

En undersøkelse publisert i Tidsskriftet i 2002 viste at norske avisers omtale av nye legemidler ofte var ukritisk positiv, ga ufullstendig informasjon og sjelden fikk frem økonomiske koblinger mellom sitert ekspert og legemiddelprodusent (4). Mye tyder på at konklusjonene fremdeles er gyldige. Da helsemyndighetene i 2009 varslet om influensapandemien, ble informasjonen kritikkløst videreformidlet av et nærmest samstemt pressekorps. Ikke før bloggere og uavhengige fagfolk kom på banen gjorde mediene forsøk på å korrigere det skremmebildet som var skapt $(5,6)$. Disse sakene har én ting til felles: en forbausende ensidig kildebruk. Å hente inn alternative og uavhengige kilder, avdekke flere sider av en sak og oppsøke kritiske røster er en journalistisk selvfølge. Hvorfor svikter dette så ofte i dekningen av helsestoff? Man tviler ikke på den aktuelle helseautoritets objektivitet, den tvil og splid som oftest eksisterer rundt nye behandlingsmetoder eller forskningsresultater kommer ikke frem, og man spør ikke om kilden har en egeninteresse $\mathrm{i}$ å presentere akkurat denne nyheten.
Når allroundjournalister har kort tid til deadline, får helsesektorens mange påvirkningsagenter lettere tilgang, enten det er prestisjetunge fagfelter, ressurssterke pasientorganisasjoner eller den farmasøytiske industris kommunikasjonsbyråer. Dermed taper de langsiktige, komplekse og vanskelige sakene, de som handler om grunnleggende ressursfordeling $i$ et begrenset helsebudsjett, om vidtrekkende helsebeslutninger tatt i lukkede styrerom eller om makt og penger i skjæringspunktet mellom offentlige helsebudsjetter og kommersielle aktører. Slike saker krever langsiktig journalistisk satsing og kompetansebygging. Det gjør også «saker» som ikke selv oppsøker redaksjonene, for eksempel om svake kronikergrupper med diagnoser som ikke selger.

Vi leger er viktige premissleverandører i helsesektoren. Norsk helsejournalistikks helsetilstand bør anspore oss til innsats. Godt helsearbeid handler også om å bygge relasjoner til dyktige og interesserte journalister, om å være tilgjengelig for mediene og om å være en etterrettelig, saklig og nyansert kilde. Ikke all kontakt med journalister skal være for å bli sitert. Ofte kan en samtale som ikke skal siteres frembringe bakgrunnskunnskap og nyanser som er med på å bygge journalistens kompetanse og innsikt. Det forutsetter at begge parter aksepterer premissene og respekterer hverandres integritet, og det forutsetter at vi leger aksepterer medienes forutsetninger og samfunnsrolle. Vi må gi slipp på våre ofte urealistiske forestillinger om at vi besitter en «sannhet» som det er journalistens jobb å formidle. Vi må være tydelige på vår faglige kunnskap, men i like stor grad forstå at journalistens rolle er å ivareta den brede samfunnsinteresse, også der den kan kollidere med våre interesser.

Norske leger har sterke meninger om helse, det vet alle som har vært i en sykehuskantine. Vi kan og bør bidra mer til et offentlig kritisk søkelys på helsesektoren enn vi gjør i dag, også ved å skrive selv. Farlige journalister på heksejakt er selvsagt ille. «Ufarlig» helsejournalistikk som bare handler om kreftvarsler og sexstillinger, er allikevel verre.

\section{Are Brean}

are.brean@legeforeningen.no

Are Brean (f. 1965) er medisinsk redaktør i Tidsskrift for Den norske legeforening, overlege ved Nevrologisk avdeling, Oslo universitetssykehus, og leder i Norsk nevrologisk forening.

\section{Oppgitte interessekonflikter: Ingen}

\section{Litteratur}

1. Hansen A. Disse symptomene må kreftsjekkes. Dagbladet 29.8.2010: 1, 14-5

2. Bør Lægeforeningen starte et medisinsk pressebyrå? Tidsskr Nor Lægeforen 1947; 67: 21.

3. Eide M. Følelser og fornuft. Mangfoldig mediemakt i fri dressur. Årsrapport. Oslo: Integrerings- og mangfoldsdirektoratet, 2009: 54-8.

4. Høye S, Hjortdahl P. «Ny vidunderpille!» - hva skriver norske aviser om nye legemidler? Tidsskr Nor Lægeforen 2002; 122: 1671-6.

5. Ulvestad E, Swensen E, Simonsen GS et al. Pandemien - bidrag til etterpåklokskap. Tidsskr Nor Legeforen 2010; 130: 169-71.

6. Hornmoen H. Kan vi få slippe nok en dommedag? Samfunnsikkerhet 2009; 2 : $18-9$. 